\title{
NILAI PENDIDIKAN KARAKTER DALAM BUKU TEKS PELAJARAN BAHASA INDONESIA SMP DI DAERAH ISTIMEWA YOGYAKARTA
}

\author{
Normawati \\ Balai Bahasa Provinsi Papua dan Provinsi Papua Barat \\ email: normawatibbpapua@yahoo.com
}

\begin{abstract}
A bstrak: Penelitian ini bertujuan mendeskripsikan nilai pendidikan karakter dalam buku teks bahasa Indonesia SMP yang dipakai di DIY. Penelitian ini merupakan penelitian deskriptif yang berwujud kajian tekstual. Sumber data penelitian adalah buku teks bahasa Indonesia SMP kelas VII, VIII, dan IX yang dipakai di DIY. Analisis data dilakukan dengan metode padan subjenis inferensial. Validitas data dengan validitas semantik sedangkan reliabilitas data dengan teknik intrarater dan interater. Hasil penelitian menunjukkan bahwa nilai pendidikan karakter dalam buku teks pelajaran Bahasa Indonesia SMP di DIY ditemukan terdiri atas lima hubungan karakter. Kelima hubungan karakter tersebut, meliputi nilai karakter manusia terhadap Tuhan, diri sendiri, sesama, lingkungan, dan bangsa. Di antara kelima hubungan karakter dalam buku teks pelajaran, hubungan karakter manusia terhadap Tuhan yang paling sedikit ditemukan. Sebaliknya, karakter manusia terhadap diri sendiri dan sesama lebih intensif kemunculannya. Hal itu menyiratkan bahwa penulis buku ingin menekankan pada aspek manusia yang memiliki kehidupan pribadi dan kehidupan sosial.
\end{abstract}

Kata Kunci: pendidikan karakter, buku teks, SM P

\section{CHARACTER EDUCATION VALUES IN THE INDONESIAN LANG UAGE TEXT BOOKS FOR JUNIOR HIGH SCHOOLS IN SPECIAL REGION OF YOGYAKARTA}

\begin{abstract}
A bstract: This study aimed at describing the character education values in the Indonesian language textbooks used for junior high schools in DIY. This research was a descriptive textual study. The data sources were the Indonesian language textbooks used in grades VII, VIII, and IX of junior high schools in DIY. Data analysis was performed using inferential subtype match. Validity of the data used semantic validity, while reliability of data used techniques of intrarater and interater. The results showed that the values of character education in the Indonesian language textbooks for junior high schools in the province consisted of five character relationships. The five relationships included the value of human characters towards God, ourselves, others, the environment, and the nation. Among the five relationships in textbooks, the character of the relationship between man and God was found to be the least. In contrast, the human character of relationship between self and others apperared to more intensive This implies that the author wants to emphasize the human aspect that has a stronger tendency towards personal and social lives.
\end{abstract}

K eyw ords: character education, textbooks, SM P

\section{PENDAHULUAN}

Eksistensi suatu bangsa ditentukan oleh karakter yang dimilikinya. Hanya bangsa yang berkarakter kuat yang mampu menjadikan dirinya sebagai bangsa yang bermartabat dan disegani oleh bangsa-bangsa lain. Oleh karena itu, menjadi bangsa yang berkarakter merupakan keinginan semua bangsa. Namun, gambaran suram masyarakat Indonesia masih dapat dirasakan setelah 50 tahun Indonesia merdeka, lebih dari empat dekade tahun setelah runtuhnya masa orde lama, dan 15 tahun tumbangnya orde baru, serta lahirnya gerakan reformasi.

Dapat disaksikan berkembangnya fragmentasi kehidupan, menguatnya egoisme pribadi dan kolektif, maraknya aneka konflik, rusaknya komunitas moral, banyaknya praktik tanpa acuan teori dan 
teori tanpa implementasi, dan meluasnya aneka kesenjangan yang mengisi pemberitaan media publik serta masih banyak lagi sisi negatif yang jika disebutkan satu per satu tidak akan habis-habisnya. Identitas karakter bangsa semakin tidak jelas, nyaris kehilangan jati diri. Menghormati jabatan lebih penting daripada menghormati pribadi sebagai manusia. Pemahaman dan penghormatan manusia dan kemanusiaan sudah terlupakan.

Semua hal di atas barangkali bersumber pada terabaikannya atau bahkan tidak adanya konseptualisasi karakter Indonesia dan terapannya dalam pembangunan dan pendidikan karakter yang diletakkan pada konsep perkembangan manusia sebagai pribadi maupun komunitas. Komunikasi tidak santun di forum publik seperti pada berbagai persidangan mengisyaratkan hilangnya kesantunan dan moralitas. Materi, jabatan, dan kekuasaan, mengabaikan, membutakan, bahkan mematikan moralitas. Pertimbangan moral sudah tidak masuk dalam hitungan, pertimbangan tolong menolong dan gotong-royong sudah jauh dari jangkauan.

Lickona (1991:13) mengungkap bahwa ada sepuluh tanda-tanda zaman yang harus diwaspadai karena jika tanda-tanda ini sudah ada, berarti sebuah bangsa se dang menuju kehancuran. Tanda-tanda yang dimaksud adalah (1) meningkatnya kekerasan di kalangan remaja; (2) penggunaan bahasa dan kata-kata yang memburuk; (3) pengaruh peer-group yang kuat dalam tindak kekerasaan; (4) meningkatnya perilaku merusak diri, seperti penggunaan narkoba, alkohol, dan seks bebas; (5) semakin kaburnya pedoman rasa hormat kepada orang tua dan guru; (6) rendahnya rasa tanggung jawab individu dan warga negara; (7) membudayanya ketidakjujuran; dan (8) adanya rasa saling curiga dan ke- bencian di antara sesama. Jika dicermati, ternyata kesepuluh tanda zaman tersebut sudah ada di Indonesia.

Sehubungan dengan itu perlu dicari strategi khusus dalam memecahkan persoalan tersebut melalui berbagai bidang, antara lain melalui bidang pendidikan. Pendidikan bahasa dan sastra Indonesia berperan penting dalam upaya menghasilkan generasi yang berkarakter, yakni generasi yang dapat menegakkan nilai-nilai moral, keadilan, dan kemanusiaan. Ditegaskan dalam Kurikulum 2004 dan 2006 bahwa belajar bahasa adalah belajar berkomunikasi dan belajar sastra adalah belajar menghargai manusia dan nilai-nilai kemanusiaannya. Namun, berdasarkan survei terbatas pada perilaku peserta didik di SMP dan wawancara dengan guru bahasa Indonesia di Daerah Istimewa Yogyakarta bahwa tujuan belajar bahasa tersebut belum tercapai dengan baik.

Buku merupakan variabel penting bagi keberhasilan pendidikan dan pembelajaran. Namun, sampai saat ini belum banyak upaya penyusunan buku ajar yang mengandung nilai-nilai pendidikan karakter secara sistemik dan sistematis. Oleh karena itu, penyusunan buku ajar yang dikemas dengan berbasis pendidikan karakter perlu dilakukan.

Beberapa penelitian menunjukkan bahwa integrasi nilai pendidikan karakter dalam buku teks masih sangat minim. Dalampenelitiannya, Kurniawan (2011) mengungkap bahwa dalam buku teks pelajaran Bahasa Indonesia SD kelas 4, 5, dan 6 terdapat nilai-nilai budaya dan keteladanan yang dapat membentuk karakter peserta didik. Namun, nilai-nilai tersebut diungkap secara tersirat sehingga pembaca/ peserta didik tidak dapat memahaminya dengan jelas. Di pihak lain, dalam penelitian Hartono (2011) menyatakan bahwa ti- 
dak semua buku teks bahasa Inggris SMA membahas topik korupsi, toleransi beragama, dan gender. Hal ini menandakan minimnya nilai-nilai pendidikan karakter dalam buku teks. Oleh karena itu, berdasarkan latar belakang di atas, penelitian ini berusaha mendeskripsikan wujud nilai pendidikan karakter dalam buku teks peIajaran bahasa Indonesia SM P di DIY.

Secara teoretis, hasil penelitian ini diharapkan dapat memberikan manfaat dalam pengembangan ide dasar tentang kebutuhan pendidikan karakter dalam buku teks pelajaran. Adapun secara praktis, penelitian ini dapat dijadikan sebagai sarana pengembangan materi ajar bagi guru dan penulis buku teks pelajaran.

Pentingnya buku teks pelajaran tidak dapat dibantah. Harmer (2007:182) menyatakan bahwa sebagian besar guru di seluruh dunia menggunakan buku teks pelajaran untuk membantu peserta didik, memberikan struktur dan arahan bagi guru dalam mengajar. Buku teks pelajaran, kata Cunningswort (1995:7) hendaknya dipandang sebagai sebuah sumber dalam mencapai tujuan umum dan tujuan khusus pembelajaran yang telah ditetapkan sesuai dengan kebutuhan peserta didik. Buku teks pelajaran memiliki peran ganda dalam pembelajaran bahasa dan dapat berfungsi, antara lain sebagai (1) sumber untuk bahan presentasi lisan atau tertulis; (2) sumber aktivitas bagi praktik dan interaksi komunikatif siswa; (3) sumber referensi untuk siswa mengenai aspek kebahasaan (tata bahasa, kosakata, dan lain-lain); dan (4) sumber rangsangan ide bagi aktivitas bahasa di kelas.

Peran dan fungsi buku tersebut sejalan dengan pendapat Abbs \& Freebairn (Cunningswort, 1995:97) akan kebutuhan peserta didik dalam belajar bahasa. A bbs \& Freebairnm mengemukakan bahwa kebu- tuhan peserta didik dalam mempelajari bahasa meliputi: (1) berkomunikasi secara efektif; (2) mengenal sistem bahasa; (3) menghadapi tantangan; (4) mendalami mata pelajaran; dan (5) persilangan budaya.

Penekanan fungsi buku teks pelajaran di kelas juga dikemukakan oleh Loveridge (Muslich, 2010:56), bahwa pelajaran di dalam kelas sangat bergantung pada buku teks dan dalam keadaan guru tidak memenuhi syarat benar, buku teks merupakan pembimbing dan penunjang dalam mengajar. Sementara itu, bagi peserta didik, buku teks bertugas sebagai dasar untuk belajar sistematis, untuk memperteguh, mengulang, dan untuk mengikuti pelajaran Ianjutan.

Buku teks pelajaran juga mengomunikasikan nilai-nilai sosial budaya, baik secara langsung maupun secara tidak langsung. Inilah yang disebut sebagai "kurikulum tersembunyi" yang merupakan bagian dari program mendidik, tetapi tidak dinyatakan dan tidak diperlihatkan. Hal itu menurut Cunningswort (1995:91) dapat berupa ungkapan sikap dan nilai yang secara sadar dilakukan, tetapi tetap mempengaruhi isi dan kesan akan bahan pengajaran dan sesungguhnya pada kurikulum secara keseluruhan.

Penyusunan buku teks pelajaran perlu memperhatikan nilai pendidikan karakter di dalamnya. Dengan membaca buku teks yang berisi nilai-nilai pendidikan karakter, akan membuat peserta didik menjadi lebih bermartabat. Sebagaimana dinyatakan Muslich yang disitir dari Musse (2010:56) bahwa peranan buku teks bagi peserta didik akan berpengaruh terhadap kepribadiannya, walaupun pengaruh itu tidak sama antara peserta didik yang satu dengan yang lainnya. Dengan membaca buku teks, peserta didik akan terdorong untuk berpikir dan berbuat positif, misal- 
nya memecahkan masalah yang dilontarkan dalam buku teks, mengadakan pengamatan yang disarankan dalam buku teks atau melakukan pelatihan yang diinstruksikan dalam buku teks. Dengan adanya dorongan yang konstruktif tersebut, dorongan atau motif-motif yang tidak baik atau destruktif akan berkurang atau terhalangi. Oleh karena itu, Musse menekankan dua peran buku teks terhadap peserta didik, yakni (1) dapat mendorong perkembangan yang baik dan (2) menghalangi perkembangan yang tidak baik.

Karena yang dianalisis adalah buku teks pelajaran bahasa Indonesia SMP, nilai karakter yang dijadikan dasar analisis, yakni mengikuti butir-butir SKL SMP (Permendiknas Nomor 23 Tahun 2006) dan SK/ KD (Permendiknas Nomor 22 Tahun 2006) se banyak dua puluh butir dengan berbagai variannya. Pertama, nilai karakter dalam hubungannya dengan Tuhan YME, meliputi nilai religius. Kedua, nilai karakter dalam hubungannya dengan diri sendiri, meliputi: (1) jujur; (2) bertanggung jawab; (3) bergaya hidup sehat; (4) disiplin; (5) kerja keras; (6) percaya diri; (7) berjiwausaha; (8) berpikir logis, kritis, kreatif, dan inovatif; (9) mandiri; (10) ingin tahu; dan (11) cinta ilmu. Ketiga, nilai karakter dalam hubungannya dengan sesama manusia, meliputi: (1) sadar akan hak dan kewajiban diri dan orang lain; (2) patuh pada aturanaturan social; (3) menghargai karya dan prestasi orang lain; (4) santun; dan (5) demokratis. Keempat, nilai karakter dalam hubungannya dengan lingkungan, meliputi: (1) peduli sosial dan (2) lingkungan. Kelima, nilai kebangsaan, meliputi: (1) nasionalisme dan (2) menghargai keberagaman.

\section{METODE}

Penelitian ini merupakan penelitian deskriptif, yaitu menganalisis dan mendes- kripsikan data secara objektif tentang wujud nilai pendidikan karakter dalam buku teks pelajaran bahasa Indonesia SMP di DIY. Subjek penelitian berupa buku teks BSI yang dipakai di SMP di DIY kelas VII, VIII, dan IX sebanyak 15 buah. Sampel dipilih secarapurposive sampling, yaitu dengan memilih buku teks yang paling banyak dipakai di SMP kelas VII, VIII, dan IX di empat kabupaten dan satu kota karena mempunyai dampak yang besar. Analisis data dilakukan dengan metode padan subjenis inferensial. Validitas data dengan validitas semantik, sedangkan reliabilitas data dengan teknik intrarater dan interater.

Kelima belas sampel tersebut adalah sebagai berikut. Pertama, Bahasa Indonesia SM P/M Ts Kelas VII oleh Atikah Anindyarini \& Sri Ningsih, Depdiknas, 2008 (BI/ VII/ AA-SN ). Kedua, Bahasa Indonesia Bahasa Kebanggaanku untuk SM P/M Ts Kelas VII oleh Sarwiji Suwandi \& Sutarmo, Depdiknas, 2008 (BIBK/ VII/ SS-S). Ketiga, Bahasa Indonesia untuk SMP Kelas VII oleh Nurhadi, Dawud, \& Yuni Pratiwi, Erlangga, 2007 (BI/ VII/ N-D-YP). Keempat, Bahasa dan Sastra Indonesia 1 untuk SM P/M Ts Kelas VII oleh Maryati-Sutopo, Depdiknas, 2008 (BSI/ VII/ M-S). Keenamn, Bahasa Indonesia SM P Kelas VII Semester Pertama dan Kedua $1 A \& 1 B$ oleh Pardjimin, Yudhistira, 2007 (BIs1.2/ VII/ P). Ketujuh, Berbahasa dan Bersastra Indonesia 2 SM P/M Ts Kelas VIII oleh Asep Yudha Wirajaya \& Sudarmawarti, Depdiknas, 2008 (BBI/ VIII/ AYW-S). Kedelapan, M embuka Jendela IImu Pengetahuan Bahasa dan Sastra Indonesia 2 untuk SMP/ M Ts Kelas VIII oleh Dwi Hariningsih, Bambang Wisnu, \& Septi Lestari, Depdiknas, 2008 (MJIPBSI/ VIII/ DH-BW-SL). KesembiIan, Bahasa Indonesia untuk SM P Kelas VIII oleh Nurhadi, Dawud, \& Yuni Pratiwi, Erlangga, 2007 (BI/ VIII/ N-D-YP). Kesepuluh, Contextual Teaching and Learning Bahasa In- 
donesia SM P/M Ts Kelas V III E disi 4 oleh Kisyani Laksono dkk., Depdiknas, 2008 (CTLBI/ VIII/ KL). Kesebelas, Bahasa Indonesia SM P Kelas VIII Semester Pertama dan Kedua, 2A \& 2B oleh Pardjimin, Yudhistira, 2007 (BIs1.2/ P). Keduabelas, Berbahasa dan Bersastra Indonesia SMP/MTs Kelas IX Oleh Asep Yudha Wirajaya \& Sudarmawarti, Penerbit Depdiknas, 2008 (BBI/IX/ AYW-S). Keduabelas, Bahasa Indonesia SM P/M Ts Ke las IX Oleh Atikah Anindyarini, Yuwono, \& Suhartanto, Depdiknas, 2008 (BI/IX/ AA-Y-S). Ketigabelas, Bahasa Indonesia untuk SM P K elas IX oleh Nurhadi, Dawud, \& Yuni Pratiwi, Erlangga, 2007 (BI/ IX/ N-DYP). Keempatbelas, Contextual Teaching and Learning Bahasa Indonesia SM P/M Ts K elas IX Edisi 4 oleh Nas Haryati dkk., Depdiknas, 2008 (CTLBI/ IX/ NH). Kelimabelas, Bahasa Indonesia SM P K elas IX Semester Pertama dan Kedua, 3A \& 3B oleh Pardjimin, Yudhistira, 2007 (Bls1.2/ IX/ P).

Kelima belas buku tersebut dianalisis muatan nilai pendidikan karakternya de ngan menggunakan butir-butir SKL SMP (Permendiknas Nomor 23 Tahun 2006) dan SK/ KD (Permendiknas Nomor 22 Tahun 2006) yang telah dikemukakan di atas. Hasil analisis terhadap kelima belas buku tersebut dapat dilihat pada paparan berikut.

\section{HASIL DAN PEMBAHASAN}

Berdasarkan pengamatan pada lima belas buku teks pelajaran Bahasa Indonesia SMP di DIY, ditemukan lima substansi wujud pendidikan karakter. Lima substansi wujud pendidikan karakter tersebut, yakni wujud karakter manusia terhadap Tuhan, karakter manusia terhadap diri sendiri, karakter manusia terhadap sesama, karakter manusia terhadap lingkungan, dan karakter manusia terhadap bangsa dengan varian masing-masing.
Unsur pendidikan karakter yang terlihat intensif ada pada nilai karakter manusia dalam hubungannya dengan diri sendiri dan sesama. Di pihak lain, nilai karakter manusia dalam hubungannya dengan lingkungan, bangsa, dan Tuhan YME kurang dominan. Dominannya tema-tema unsur kehidupan pribadi menunjukkan dominannya nilai karakter manusia dalam hubungannya dengan diri sendiri, sedangkan tema-tema kritik sosial dan kepahlawanan menunjukkan dominannya nilai karakter manusia terhadap sesama. Lebih dominannya nilai karakter manusia terhadap diri sendiri dan sesama tampaknya disebabkan penulis buku ingin menekankan pada aspek manusianya yang memiliki kehidupan pribadi dan kehidupan sosial.

Di pihak lain, penelitian Nurgiyantoro \& Efendi (2013) menunjukkan bahwa para guru SMP/ MTs di DIY menyetujui sejumlah prioritas nilai yang mesti mendapatkan perhatian utama adalah nilai-nilai religius, jujur, cinta tanah air, peduli lingkungan, dan tanggung jawab, serta sejumlah nilai lain pada urutan berikutnya, yaitu nilai kreatif, gemar membaca, disiplin, dan mandiri. Daftar nilai yang dipilih untuk dibelajarkan juga sengaja diambil dari $\mathrm{Ke}$ mendiknas (2010) yang disarankan untuk dibelajarkan di sekolah.

\section{Wujud Nilai Pendidikan Karakter dalam Buku Teks Pelajaran Bahasa Indonesia SMP di DIY}

Pembahasan mengenai wujud unsur pendidikan karakter dalam buku teks pelajaran bahasa Indonesia ini dibagi menjadi lima kategori karakter berdasarkan panduan nilai pendidikan karakter dari Kemendiknas (2010:16) sekaligus juga pada Standar Kompetensi Lulusan (SKL), yakni nilainilai perilaku manusia dalam hubungannya dengan Tuhan Yang Maha Esa, diri 
sendiri, sesama manusia, dan lingkungan serta kebangsaan. Berikut deskripsi wujud unsur pendidikan karakter dalam buku teks ajar BSI SMP kelas VII, VIII, dan IX di DIY.

\section{Nilai Karakter dalam Hubungannya de- ngan Tuhan (Religius)}

Berdasarkan hasil analisis dari 15 buku teks ditemukan karakter yang paling menonjol dalam hubungan manusia dengan Tuhan adalah karakter taat kepada Tuhan Yang Maha Esa muncul sebanyak 52 kali serta karakter bersyukur dan tawakal muncul sebanyak 25 kali. Berikut paparan masin-masing yang menunjukkan karakter manusia terhadap Tuhan dalam buku teks.

\section{Taat kepada Tuhan Yang M aha Esa}

Hasil temuan menunjukkan bahwa karakter manusia terhadap Tuhan dengan varian taat kepada Tuhan YME terlihat paling dominan muncul pada buku 3 (BI/ VII/ N-D-YP), yakni sebanyak 5 kali, bukubuku teks terbitan Depdiknas dan Yudhistira, karakter ini muncul 3 kali dan 2 kali. Sementara itu, terdapat 4 buku teks yang tidak memiliki varian sembahyang/ berdoa sama sekali, yakni pada buku 6 (BBI/ VIII/ AYW-S), buku 9 (CTLBI/ VIII/ KL), buku 11 (BBI/ IX/ AYW-S), dan Buku 12 (BI/ IX/ AA-Y-S).

Karakter taat terlihat pada Buku 1 (BI/ VII/ AA-SN ) dalampantun agama (hlm. 23) dan pada Buku 2 (BIBK/ VII/ SS-S) halaman 16-17. Dari kutipan pantun tersebut, wujud ketaatan kepada Tuhan YME menganjurkan untuk sembahyang agar kelak di kemudian hari tidak mendapat siksa di dalam kubur. Hal yang sama terlihat pada Buku 13 (BI/ IX/ N-D-YP) dalam petikan syair "Syair Perahu" (hlm.87-88) dan Buku 14 (CTLBI/ IX/ NH) halaman 69. Syair tersebut banyak mengaitkan hubung- an manusia dengan alam semesta (kosmologi), manusia dengan alam gaib (teologi), dan manusia dengan manusia itu sendiri (berkaitan dengan aksiologi). Penyair menyeru generasi muda khususnya supaya mengenali diri sendiri agar senantiasa waspada dan selalu ingat kepada Allah. Dalam waktu yang bersamaan, penyair mengingatkan juga agar manusia senantiasa melakukan amal ibadah yang berguna.

Karakter taat kepada Tuhan juga diperlihatkan pada Buku 13 (BI/ IX/ N-D-YP) dalam cerpen "Babby Sitter Gaul" (hlm. 15-18), buku 5 (BIs1.2/ VII/ P) dalam dongeng "Terbukti, Teruji, dan Terpuji" (hlm. 1-2). Selain itu, karakter taat berupa perintah sembahyang/salat muncul pada Buku 3 (BI/ VII/ N-D-YP) dalam bentuk puisi (hlm. 156), taat dalam bentuk berdoa muncul pada Buku 4 (BSI / VII/ M-S) dalam puisi “Doa” (hlm. 101), dan taat kepada dewa pada Buku 2 (BIBK/ VII/ SS-S) dalam cerita "Tukang Cukur Sanwe" (hlm. 7678).

Selain sembahyang dan berdoa, bentuk taat terhadap Tuhan YME yang lain adalah bertobat. Karakter taat dalam bentuk bertobat muncul pada Buku 9 (CTLBI/ VIII/ KL) halaman 67-68. Kutipan tersebut memperlihatkan Gito Rollies atau biasa dipanggil Kang Gito yang sudah berpuluh tahun merupakan ikon artis yang melenceng dari tuntunan moral, pecandu ganja, dan penganut kehidupan bebas. Berkat hidayah Allah dan tuntunan keluarganya, kang Gito berhasil mengubah hidupnya ke arah yang lebih positif. Orientasi hidupnya telah berubah dari cinta dunia menjadi cinta akhirat. Hal itulah yang membuatnya menjadi tenang. 


\section{Bersyukur (Berterima Kasih kepada Tu- han) dan Tawakal}

Bentuk karakter syukur ditemukan pada buku teks berupa kutipan puisi "A nugerah Laut" (hlm. 163) pada Buku 9 (CTLBI/ VIII/ KL). Perwujudan rasa syukur juga dapat direalisasikan dengan cara lisan dan perbuatan, seperti diungkap dalam kutipan puisi "Tuhan" (hlm. 71-72) pada Buku 14 (CTLBI/ IX/ NH). Diberikan mata, telinga, kaki, dan akal merupakan wujud ciptaan Tuhan terhadap makhluknya yang tiada tara. Dengan adanya mata, telinga, kaki, dan akal untuk dapat melihat, mendengar, menyelusuri nikmat Tuhan akan menyadarkan manusia untuk selalu bersyukur.

Selain karakter syukur, dalam buku teks juga terdapat karakter tawakal, seperti pada Buku 2 (BIBK/ VII/ SS-S) dalam teks "Saudagar Jerami" (hlm. 62-64). Kutipan tersebut menggambarkan seorang yang bernama Taro setiap hari bekerja keras di ladang namun harapannya untuk menjadi orang kaya belum terkabulkan. Oleh karena itu, setiap hari sepulang bekerja, Taro masuk ke kuil berdoa dan berserah diri meminta jalan untuk menjadi kaya. Taro sudah menyerahkan sepenuhnya kepada Dewa Rahmat akan nasibnya setelah melalui usaha dan bekerja keras. Sejalan waktu, permintaan Taro kemudian dikabulkan Dewa. Taro menjadi kaya dan selalu menolong sesamanya.

Dengan adanya contoh hubungan karakter manusia terhadap Tuhan dalam buku teks, diharapkan dapat berpengaruh terhadap pembentukan karakter peserta didik. Hal itu terlepas dari dua pandangan yang berbeda mengenai pendidikan agama dan pendidikan karakter. Karakter dalam etika sekuler hanya berfokus pada manusia dengan sesamanya atau dengan alam se kitarnya. Di pihak lain, dalam pandangan tokoh etika Islam, karakter harus dimulai dengan membangun hubungan baik dengan Allah SWT dan Rasulullah, kemudian berlanjut dengan hubungan sesama dan lingkungan.

\section{Nilai Karakter dalam Hubungannya de- ngan Diri Sendiri}

Berdasarkan hasil analisis terhadap lima belas buku teks ditemukan karakter manusia terhadap diri sendiri terdiri atas 12 varian karakter. Varian karakter tersebut, yakni (1) jujur, adil, dan rendah hati; (2) bertanggung jawab dan mandiri; (3) bergaya hidup sehat; (4) rajin, disiplin, tertib, hemat, sportif, dan tegas; (5) semangat dan kerja keras; (6) percaya diri; (7) berjiwa wirausaha; (8) berpikir logis, kritis, aktif, kreatif, inovatif, dan cerdas; (9) ingin tahu; (10) cinta ilmu dan gemar membaca; (11) tabah dan sabar, ikhlas, loyal, menepati janji; dan (12) teliti, cermat, hati-hati.

Dari dua belas varian karakter dalam buku teks, terlihat varian rajin, disiplin, tertib, hemat, sportif, dan tegas yang paling dominan, yakni sebanyak 79 kali. Varian berpikir logis, kritis, aktif, kreatif, dan inovatif menyusul sebanyak 62 kali, bergaya hidup sehat 55 kali, jujur, adil, rendah hati sebanyak 49 kali. Varian berjiwa wirausaha sebanyak 39 kali. Selebihnya varian karakter yang kurang dari 35 kali, seperti dipaparkan berikut.

\section{Jujur, Adil, dan R endah Hati}

Beberapa upaya pewarisan karakter kejujuran dalam buku teks bahasa Indonesia SMP adalah melalui berbagai cerita, dongeng, fabel, cerpen, puisi, dan bentuk teks lainnya. Konteks ketidakjujuran yang biasa dipertontonkan dalam dunia pendidikan muncul pada Buku 8 (BI/ VII/ N-DYP) dalam cerpen "Wow, Bocoran Soal!" (hlm. 57-59). Cerpen tersebut menggam- 
barkan seorang peserta didik yang menawarkan bocoran soal-soal ujian kepada teman-temannya. Namun, salah seorang peserta didik bernama Sita menolak melakukan kecurangan dan memilih belajar keras untuk keberhasilan ujiannya. Hal yang sama pada Buku 4 (BSI/ VII/ MS) dalam teks "Karena Menyontek" (hlm. 99). Tokoh Aku menyesali perbuatannya telah mencontek pada saat ujian. Walaupun mendapat nilai tinggi, tokoh Aku selalu dibayangi rasa bersalah.

Tema ketidakjujuran juga diungkap pada Buku 1 (BI/ VII/ AA-SN) dalam bentuk puisi bertema korupsi "Kepada Koruptor" karya Abdurahman Faiz dan puisi "N egeriku" karya K. (hlm. 120). Puisi tersebut merupakan contoh yang mengungkap praktik korupsi, kolusi, dan nepotisme pe merintah dan elit berkuasa yang berimbas pada penderitaan rakyat yang berkepanjangan. Melalui puisi "Kepada Koruptor", penyair ingin mengungkapkan keprihatinannya terhadap kondisi rakyat Indonesia yang menderita akibat ulah para koruptor yang memakan uang rakyat. Penderitaan tersebut dapat dilihat dari air mata para bocah di lampu merah, jeritan kelaparan, keinginan untuk melanjutkan sekolah, dan orang-orang miskin di negeri ini. Lewat puisi, penyair memohon kepada koruptor agar jangan memakan uang rakyat. Puisi ini jelas memberikan gambaran pemimpin atau para elit yang berkuasa yang tidak memiliki karakter jujur dalam mengelola negara.

Begitu pula dengan puisi "Negeriku", penyair menggambarkan negara yang makmur, namun di dalamnya penuh dengan ketidakjujuran para pemimpin dan pemegang kekuasaan. Akibatnya, sungguh ironis, rakyat melarat di tengah gelimang kekayaan kaum konglomerat dan para penguasa.Tatkala kejahatan korupsi telah ber- sifat banal, itu berarti menjadikan praktik ini sebagai sesuatu yang dianggap lumrah, biasa, bahkan menjadi prinsip penggerak kehidupan sehari-hari. Korupsi seolah menjadi aturan, nilai, dan norma yang mengarahkan gerak manusia dalam setiap bidang kehidupan.

Dari bahasan di atas diharapkan peserta didik mampu menumbuhkan kesadaran terhadap pentingnya pemberantasan dan pencegahan korupsi. Selain itu, lewat teks-teks tersebut diharapkan tumbuhnya kepercayaan pada diri generasi muda bangsa pada pentingnya kerja keras dan kejujuran.

\section{Bertanggung Jawab dan Mandiri}

Karakter tanggung jawab dalam buku teks pelajaran BSI SMP, antara lain pada Buku 1 (BI/ VII/ AA-SN) dalam teks "Surat untuk Raja" (hlm. 35-36). Ketekunan, kesabaran, dan tanggung jawab akan benarbenar terlihat pada saat menghadapi ujian. Selain itu, karakter tanggung jawab juga terlihat muncul pada Buku 8 (BI/ VIII/ ND-YP). Karakter tanggung jawab tertuang dalam teks yang mengisahkan seorang Muljo Adji A. G., sekretaris perusahaan PT PLN (hlm. 4)

Di samping karakter tanggung jawab, karakter mandiri juga muncul dalam buku teks. Pelan tapi pasti kemandirian itu dikenalkan pada anak bahwa segala sesuatu harus diraihnya dengan perjuangan, seperti pada Buku 11 (BBI/IX/AYW-S) dalam cerpen "Bingkisan Lebaran" (hlm. 12-13) dan pada cerpen "Sebatang Kara" (hlm. 32-33). Cerpen "Sebatang Kara" menggambarkan seorang anak laki-laki bernama Ogal, orang tuanya meninggal dunia. Ibu gurunya yang merasa prihatin dengan hidup Ogal yang sudah sebatang kara meminta agar tinggal di rumahnya. Walaupun dia tinggal di rumah gurunya yang serba 
kecukupan, Ogal tidak pernah duduk bermalas-malasan. Dia tetap mengerjakan pekerjaan rumah sama seperti ketika orang tuanya masih hidup. Kebiasaannya bekerja keras, tidak suka menggantungkan diri pada orang lain, dan terbiasa hidup prihatin membuatnya tidak suka berfoya-foya walaupun hidupnya sudah nyaman. Dengan adanya nilai karakter ini, diharapkan peserta didik mampu mengimplementasikan juga dalam kehidupan nyata.

\section{Bergaya Hidup Sehat}

Nilai karakter bergaya hidup sehat banyak ditemukan dalam buku teks BSI. Nilai karakter tersebut muncul dalam buku 1(BI/ VII/ AA-SN) pada teks "Narkoba Ternyata Menular" (hlm. 44). Di dalam teks tersebut, ditanamkan kesadaran akan bahaya narkoba bagi generasi muda sehingga mereka mengadakan gerakan kampanye antinarkoba. Berani mengatakan "tidak" pada narkoba merupakan sikap positif pada diri remaja yang patut ditiru.

Karakter gaya hidup sehat juga diungkap berturut-turut dalam Buku 8 (BI/ VIII/ N-D-YP) berupa teks "Resep Hidup Sehat dan Damai" (hlm. 132), "10 Cara agar Hidup Lebih Tenang dan Damai" (hlm. 134-135), dan kutipan berita pentingnya makanan organik untuk dikonsumsi (hlm. 156-157). Dari kutipan berita tersebut dijelaskan pentingnya makanan organik untuk dikonsumsi. Makanan organik yang dimaksud adalah makanan yang bahan bakunya tumbuh tanpa pestisida, tanpa pupuk kimia, dan tanpa rekayasa genetika. Kutipan teks "Mengenal Zat Tambahan pada Makanan" (hlm. 23-24) pada Buku 9 (CTLBI/ VIII/ KL) merupakan bagian pengenalan karakter gaya hidup sehat pada peserta didik. Teks ini memberikan wawasan kandungan komposisi dan pemilihan yang bijak pada bahan makanan dengan sedikit menggunakan zat adiktif.

Dengan adanya bahasan mengenai pentingnya karakter gaya hidup sehat dalam buku teks SMP ini, diharapkan peserta didik dapat bijak, selektif, dan cerdas menyikapi hidup sehingga tujuan pendidikan untuk melahirkan generasi yang kuat secara menyeluruh, akal, jiwa, dan ruhaninya terlaksana. Dengan demikian, akan tercipta konfigurasi karakter dalam konteks totalitas proses psikologis dan sosial-kultural, yakni olahraga dan kinestetik.

\section{Disiplin, Rajin, Hemat, Sportif, dan Tegas \\ Karakter disiplin dalam buku teks} SMP disampaikan dalam berbagai teks, seperti dalam teks wacana, cerita, dan slogan. Buku yang memuat karakter disiplin, antara lain Buku 1 (BI/ VII/ AA-SN) dalam teks yang memperlihatkan carut marut "Kondisi Lalu Lintas Indonesia" (hlm.16), pada teks cerita "Marty" (hlm. 55), Buku 3 (BI/ VII/N-D-YP) dalam teks wacana yang menggambarkan "Kedisplinan PNS" (hlm. 235), dan Buku 5 (BIs1.2)/ VII/ P) dalam cerita "Berpacu dengan Cita-Cita" (hlm.5354A).

Kedisiplinan merupakan cermin keteraturan hidup seseorang. Tidak ada yang lebih penting dalam manajemen diri dibandingkan dengan kedisiplinan. Selain pentingnya menemukan arah dan tujuan hidup yang jelas, kedisiplinan merupakan syarat mutlak untuk mencapai impian atau melaksanakan misi hidup. Disiplin dalam mengembangkan diri (life time improvement) dalam segala aspek, misalnya disiplin dalam mengelola waktu dan uang, disiplin dalam melatih keterampilan setiap bidang yang dipilih. Untuk itu, belajar dari keberhasilan orang-orang yang sukses luar biasa dalam sejarah umat manusia sangatlah penting dilakukan. Kesuksesan yang diraih 
orang-orang terdahulu adalah berkat disiplin yang ditanamkan dalam diri mereka sejak dini.

Tujuan utama dari disiplin bukanlah hanya sekadar menuruti perintah atau aturan saja. Patuh terhadap perintah dan aturan merupakan bentuk disiplin jangka pendek. Bentuk disiplin jangka panjang ada dalam tujuan pendidikan disiplin, yaitu disiplin yang tidak hanya didasarkan pada kepatuhan terhadap aturan tetapi le bih kepada pengembangan kemampuan untuk mendisiplinkan diri.

Selain disiplin, karakter rajin dan hemat juga terdapat dalam buku teks. Rajin menurut KBBI (Pusat Bahasa, 2008:1134) adalah suka bekerja (belajar dan sebagainya), getol, sungguh-sungguh bekerja, se Ialu berusaha giat, kerapkali, terus-menerus. Hemat menurut KBBI (Pusat Bahasa, 2008:490) adalah berhati-hati dalam membelanjakan uang, dan sebagainya, tidak boros, cermat. Berdasarkan temuan penelitian, karakter hemat dalam buku teks banyak ditemukan pada dongeng, novel, dan teks-teks lainnya. Hal itu terlihat pada Buku 5 (BIs1.2)/ VII/ P) dalam kutipan dongeng "Semut yang Hemat" (hlm. 7475A ), Buku 11 (BBI/ IXI AYW-S) dalam kutipan novel "Azab dan Sengsara" (hlm. 127-129).

\section{Semangat dan Kerja Keras}

Karakter semangat dan kerja keras ditemukan dalam beberapa buku teks, antara lain pada Buku 8 (BI/ VIII/ N-D-YP) yang menggambarkan kisah nyata yang dilakoni seorang mahasiswa UIN Syarif Hidayatullah, Ciputat, Tangerang (hlm. 27). Hal yang sama dilakoni Naseri (hlm. 50-51) dalam Buku 13 (BI/IX/ N-D-YP). Kisah ini dihadapi oleh seorang peserta didik dari sebuah SMK yang bernama $\mathrm{Na}$ seri. Demi membiayai sekolahnya, Naseri melakukan pekerjaan mengangkat sampah setiap hari sebelum berangkat ke sekolah. Naseri dengan semangat dan kerja keras tidak gengsi melakoni pekerjaan itu yang padasebagian orang menganggapnya mendekati hina. Dalam benak Naseri, hanya bekerja keras yang dapat mengantarkannya menjemput hari depan yang lebih baik dari hari ini.

Semangat dan kerja keras yang ditunjukkan kedua orang tersebut merupakan upaya memaslahatkan manusia dan lingkungannya. Artinya, tidak dikategorikan orang sebagai kerja keras orang yang menghabiskan waktunya untuk mengedarkan narkoba atau membuat ide untuk merampok di bank karena keduanya dilakukan bukan untuk memberikan kebaikan kepada manusia. Akan tetapi, bekerja keras dengan halal tanpa menjadi seorang peminta-minta seperti ditekankan dalam AIquran Surat Al Ankabut ayat 69 yang artinya " $D$ an orang-orang yang berjihad untuk (mencari keridhaan) Kami. Kami akan tunjukkan kepada mereka jalan-jalan Kami. Dan sungguh Allah beserta orang-orang yang berbuat baik.

\section{Percaya Diri}

Percaya diri menurut Kemendiknas (2010:17) adalah sikap yakin akan kemampuan diri sendiri terhadap pemenuhan tercapainya setiap keinginan dan harapannya. Salah satu kutipan karakter percaya diri dalam buku teks BI SMP diungkap dalam Buku 11 (BBI/ IXI AWY-S) pada teks drama (hlm. 230-231). Kutipan drama tersebut memberikan gambaran bahwa hidup harus percaya pada diri sendiri, percaya kepada kekuatan sendiri, tidak bergantung pada dukun atau kekuatan lain. Percaya pada diri sendiri untuk meraih kesuksesan. Namun, walaupun zaman sudah mengglobal, 
masih ada saja manusia Indonesia yang percaya pada hal-hal gaib.

Benar yang pernah dideskripsikan budayawan Mochtar Lubis (2001) bahwa karakter bangsa Indonesia yang negatif, yakni masih percaya pada takhyul. Dulu dan sekarang juga, masih ada yang demikian, manusialndonesia percaya pada batu, gunung, pantai, sungai, danau, karang, pohon, patung, bangunan, keris, pisau, pedang, itu punya kekuatan gaib, keramat, dan manusia harus mengatur hubungan khusus dengan ini semua. Selain itu, manusia Indonesia punya watak yang lemah. Karakter kurang kuat. Manusia Indonesia kurang kuat mempertahankan atau memperjuangkan keyakinannya. Mudah apalagi dipaksa dan demi untuk "survive" bersedia mengubah keyakinannya. Oleh sebab itu, dapat dilihat pelacuran intelektual amat mudah terjadi terhadap manusia Indonesia.

Agar tidak tergelincir pada sifat feodal, percaya pada hal gaib, perlu ditumbuhkan sikap positif dalam memandang diri sendiri dengan mengatakan bahwa tidak ada kesuksesan tanpa perjuangan dan pengorbanan. Dalam berjuang, harus ada yang dikorbankan. Itulah pengorbanan demi sebuah perjuangan.

\section{Berjiwa Wirausaha}

Karakter berjiwa wirausaha dalam buku teks BSI terdapat pada kutipan, antara lain pada Buku 7 (MJIPBSI/ VIII/ DH BW-SL) dalam teks "Pendidikan Kewirausahaan” (hlm. 66). Kutipan tersebut menggambarkan pentingnya karakter berjiwa wirausaha ditanamkan dalam diri peserta didik agar memiliki pola pikir cerdas, kreatif, menghadapi tantangan seberat apa pun dalam menciptakan kreasi dan inovasi kebudayaan. Dalam Kemendiknas (2010b:19) dinyatakan bahwa dalam membangun se- mangat kewirausahaan dan memperbanyak wirausahawan, Pemerintah telah mengeluarkan Instruksi Presiden No. 4 Tahun 1995 tentang Gerakan Nasional Memasyarakatkan dan Membudayakan Kewirausahaan. Instruksi ini mengamanatkan kepada seluruh masyarakat dan bangsa Indonesia untuk mengembangkan program-program kewirausahaan. Pemerintah menyadari betul bahwa dunia usaha merupakan tulang punggung perekonomian nasional sehingga harus diupayakan untuk ditingkatkan secara terus-menerus. Melalui gerakan ini diharapkan karakter kewirausahaan akan menjadi bagian dari etos kerja masyarakat dan bangsa Indonesia sehingga dapat melahirkan wirausahawan-wirausahawan baru yang andal, tangguh, dan mandiri.

Dalam konteks ini, pendidikan kewirausahaan harus mampu mengubah pola pikir para peserta didik sebagaimana yang dikemukakan oleh Kasmir (Kemendiknas, 2010b:22). Pendidikan kewirausahaan akan mendorong peserta didik agar memulai mengenali dan membuka usaha atau berwirausaha. Pola pikir yang selalu beorientasi menjadi karyawan diputar balik menjadi berorientasi untuk mencari karyawan. Dengan demikian kewirausahaan dapat diajarkan melalui penanaman nilai-nilai kewirausahaan yang akan membentuk karakter dan perilaku untuk berwirausaha agar para peserta didik kelak dapat mandiri dalam bekerja atau mandiri usaha.

\section{Berpikir Logis, Kritis, Kreatif, Inovatif, dan Cerdas}

Karakter berpikir logis, kritis, kreatif, inovatif, dan cerdas yang terdapat dalam buku teks, antara lain kreatif dalam berkarya diungkap dalam Buku 4 (BSI/ VII/ MS) halaman 61-63. Cerminan sikap kreatif dari drama tersebut dapat dicermati dari sejumlah aktivitas yang dilakukan Ratu 
Pandan Wangi. Selain melukis, Ratu Pandan Wangi juga mengembangkan kreasinya dengan banyak menulis. Sikap Ratu Pandan Wangi itulah yang patut ditiru oleh peserta didik.

Selain sikap kreatif Ratu Pandan Wangi dalam kutipan wawancara, sikap kritis dan cerdas remaja dalam memilih tayangan juga perlu dilakukan seperti diungkap dalam Buku 9 (CTLBI/ VIII/ KL) pada teks "Sinema Remaja Tayangan Televisi Kita" dan Buku 11 (BBI/IX/ AYW-S) pada teks "A was Dehumanisasi" (hlm.122-123). Ke dua kutipan tersebut menggambarkan tayangan sineas dan iklan di televisi kering dengan nilai edukasi. Dominasi budaya membodohi akibat pengaruh tayangan media (terutama budaya menonton melalui TV) pengaruhnya pada masyarakat cukup Iuar biasa terutama generasi muda. Tontonan gaya hedonisme, mengumbar kemewahan, menebar horor, marak mewarnai tayangan televisi yang dapat menjadi ancaman yang mudah ditiru generasi muda saat ini. Kurangnya muatan budaya dan nilai edukasi dalam tayangan tersebut akan menyebabkan hilangnya karakter aktif produktif bagi generasi muda sehingga lahir gaya hidup yang konsumtif, hura-hura, eksentrik, ke mal, restoran, dan sejumlah pergaulan hedonis. Inilah penyakit nyata yang mewarnai sebagian generasi muda saat ini.

Mochtar Lubis dalam bukunya $\mathrm{M}$ anusia Indonesia (2001) menyatakan bahwa salah satu ciri karakter manusia Indonesia adalah cenderung boros. Dia senang berpakaian bagus, memakai perhiasan, berpesta-pesta. Hari ini ciri manusia Indonesia ini menjelma dalam hubungan membangun rumah mewah, mobil mewah, pesta besar, hanya memakai barang buatan luar negeri, main golf, singkatnya segala hal yang serba mahal. Dengan adanya gambaran karakter ini dalam buku teks, diharap- kan peserta didik dapat selektif dan cerdas serta tidak mengikuti gaya hidup hidup yang dapat merusak dirinya sendiri.

\section{Ingin Tahu}

Sikap dan tindakan yang selalu berupaya untuk mengetahui lebih mendalam dan meluas dari apa yang dipelajari, dilihat, dan didengar merupakan karakter rasa ingin tahu (Kemendiknas, 2010:17). Karakter rasa ingin tahu muncul pada Buku (BSI/ VII/ MS) dalam cerita rakyat "Batu Api" (hlm. 21-23) yang merupakan Cerita rakyat dari Irian Jaya diterbitkan Putra N egara.

Cerita rakyat dari Irian Jaya (Papua) tersebut menggambarkan bahwa sejak dahulu manusia itu selalu memiliki rasa ingin tahu. Dengan keingintahuan itu, maka pengetahuan dapat berkembang. Kebenaran cerita tentang sebuah batu yang dapat mengeluarkan api itu tidak dapat disangkal. Dahulu kala sebelum korek api tercipta, api dihasilkan dari gesekan benda keras. Lambat laun seiring perkembangan budaya dan pemikiran manusia terciptalah korek api. Selama sikap ingin tahu muncul, maka akan menghadirkan wujud representamen baru yang membangun dunia kehidupan baru.

\section{Cinta IImu dan G emar Membaca}

Salah satu tujuan pendidikan nasional yang dicanangkan dalam Undang-Undang Sisdiknas adalah melahirkan generasi atau peserta didik yang berilmu dan berpengetahuan. Untuk melahirkan generasi berilmu dan berpengetahuan harus memiliki karakter cinta terhadap ilmu pengetahuan dan gemar membaca. Cinta ilmu (Kemendiknas, 2010:18) adalah cara berpikir, bersikap dan berbuat yang menunjukkan kesetiaan, kepedulian, dan penghargaan yang tinggi terhadap ilmu pengetahuan. 
Karakter cinta ilmu dalam buku teks terlihat pada Buku 7 (MJIPBSI/ VIII/ DH BW-SL) dalam teks "IImuan Sedari Muda" (hlm. 89-91). Teks tersebut mengungkap perlunya menumbuhkan karakter cinta terhadap ilmu pengetahuan dan mengembangkan panggilan menjadi ilmuan sedari muda. Berbagai upaya, seperti lomba karya ilmiah, festival sains, pembangunan pusat peragaan Iptek dan Taman Pintar memiliki mata rantai utuh untuk menyemaikan bakat ilmuwan sedari muda.

Selain cinta ilmu, karakter budaya gemar membaca juga sangat penting bagi peserta didik. Kata-kata bijak yang mengatakan bahwa buku adalah jendela informasi dunia menemukan relevansinya yang semakin kuat dalam abad informasi dewasa ini. Adanya arus global yang melanda dunia dan mengandaikan semakin cepatnya arus informasi dari berbagai belahan dunia hanya dapat diikuti dengan baik jika orang mau membaca. Nurgiyantoro (2013: 47) menegaskan bahwa bangsa yang maju di dunia ini pasti didukung oleh warganya yang haus bacaan. Pentingnya budaya membaca juga telah ditegaskan Taufik Ismail dalam tulisannya yang berjudul "Agar Anak Bangsa Tak Rabun Membaca Tak Pincang Mengarang". Ia menyatakan bahwa peradaban bangsa ditentukan oleh penanaman literasi buku di sekolah melalui buku sastra. Jadi, sastra diyakini mampu memotivasi anak untuk suka membaca, mampu mengembalikan anak kepada buku.

\section{Tabah dan Sabar}

Tabah menurut KBBI (Pusat Bahasa, 2008:1370) adalah tetap dan kuat hati (dalam menghadapi bahaya dan sebagainya), berani. Beberapa kutipan teks yang mengandung karakter tabah di antaranya pada Buku 1 (BI/ VII/ AA-SN) dalam “Dongeng dari Provinsi Lampung" (hlm.107-
109). Ketabahan yang digambarkan oleh seorang ibu dalam dongeng tersebut patut diteladani. Di tengah isak tangis anaknya yang kelaparan, sang ibu berusaha dengan tabah mengolah ladang agar dapat menanam padi yang kelak akan dimasak menjadi nasi untuk anaknya. Namun, ketabahan sang ibu tidak membuahkan hasil karena sang anak yang sudah sangat kelaparan tidak dapat lagi bertahan hidup. Kutipan dongeng tersebut memberikan pesan secara tersirat bahwa peserta didik menghargai makanan yang disuguhkan orang tua (ibu) dan tidak menghambur-hamburkan makanan. Ketabahan yang sama juga diungkap pada Buku 2 (BIBK/ VII/ SS-S) dalam cerpen "Pada Tikungan Berikutnya" (hlm. 164-168), dan Buku 5 (BIs1.2/ VIIB/ P) pada lagu "Titip Rindu Buat Ayah" (hlm.64B). Kutipan lagu tersebut menggambarkan ketabahan sang ayah dalam mengarungi kerasnya kehidupan. Walaupun tubuhnya sudah renta memikul beban hidup, namun tetap saja tabah mencari nafkah untuk keluarganya.

Selain karakter tabah, karakter sabar juga terdapat dalam buku teks pelajaran. Sabar menurut KBBI (Pusat Bahasa, 2008: 1196) adalah tahan menghadapi cobaan (tidak lekas marah, tidak lekas putus asa, tidak lekas patah hati), tabah, tenang, tidak tergesa-gesa, tidak terburu nafsu.

\section{Teliti, Cermat, dan Hati-hati}

Karakter teliti menurut KBBI (Pusat Bahasa, 2008:1427) adalah cermat; seksama; hati-hati; ingat-ingat. Karakter teliti, cermat, dan hati-hati muncul pada Buku 6 (BBI/ VIII/ AYW-S) dalam kutipan teks "Melatih Kecermatan dengan Permainan Dakon" (hlm. 47-48). Kutipan teks tersebut menggambarkan bahwa di balik permainan tradisional seperti dakon mengandung banyak nilai karakter di dalamnya 
seperti ketelitian, kecermatan, kejujuran, dan ekonomis. Dengan menggalakkan permainan dakon berarti melestarikan budaya tradisional.

Selain ketelitian dalam permainan tradisional, seperti dakon, kecermatan, dan kehati-hatian juga perlu dilakukan dalam mendiagnosis kesehatan seperti diungkap pada Buku 15 (Bls1.2/ IXA/ P) dalam kutipan "Keakuratan Diagnosis Menuntut Ketelitian" (hlm.16-17A). Dari kutipan teks diungkap keakuratan dan kecermatan dalam mendiagnosis suatu penyakit dituntut ketelitian yang tinggi sehingga diperlukan alat bantu yang canggih. Selain sikap positif para pelaku medis, diperlukan juga peningkatan pengetahuan yang memadai untuk menunjang tugas dan tanggung jawabnya yang rentan dengan nyawa orang banyak. Hal itu mengingat akhir-akhir ini banyak disinyalir terjadi malpraktik di rumah-rumah sakit. Oleh sebab itu, dengan adanyapeningkatan pengetahuan dari para ahli medis yang didukung oleh alat-alat kesehatan yang super canggih diharapkan malpraktik menjadi berkurang.

\section{Nilai Karakter dalam Hubungannya de- ngan Sesama}

Nilai karakter manusia dalam hubungannya dengan sesama adalah karakter yang berhubungan dengan sesama manusia dalam masyarakat, bukan atas dasar kepentingan individu atau pribadi. Berdasarkan hasil analisis dari 15 buku teks pe lajaran ditemukan bahwa nilai karakter manusia dalam hubungannya dengan sesama sebanyak 186 kali. Varian karakter sadar akan hak dan kewajiban diri dan orang lain sebanyak 11 kali, patuh pada aturan sosial sebanyak 6 kali, menghargai karya dan prestasi orang lain sebanyak 20 kali, santun, suka menolong, tenggang rasa, gotong-royong, dan kerja sama sebanyak 125 kali, demokratis, bijaksana, dan dapat dipercaya sebanyak 24 kali. Berikut dipaparkan nilai karakter dalam hubungannya dengan sesama.

\section{Sadar akan Hak dan Kewajiban Diri dan Orang Lain}

Sadar akan hak dan kewajiban diri dan orang lain menurut Kemendiknas (2010:18), yakni sikap tahu dan mengerti serta melaksanakan apa yang menjadi milik atau hak diri sendiri dan orang lain serta tugas atau kewajiban diri sendiri serta orang lain. Karakter ini muncul salah satunya pada Buku 11 (BBI/ IX/ AYW-S) dalam cerpen "Alun-Alun Suryakencana" (hlm. 83-85). Dari kutipan cerpen tersebut digambarkan kisah seorang pejabat yang menomorsatukan kekayaan dan kejayaan dalam kehidupan, mementingkan kepentingan pribadi di atas kepentingan golongan, menggunakan tempat umum yang tidak semestinya, dan bersifat boros. Karakter pejabat sejatinya menjadi teladan bagi masyarakat, namun rakyat sudah terlalu sering melihat berbagai paradoks. Saat menikahkan anaknya, yang diberi hak istimewa dan dipandang mulia adalah pejabat dan yang berharta. Rakyat kecil dan orang biasa dibiarkan berdiri berjam-jam mengantri untuk bersalaman.

\section{Patuh pada A turan-Aturan Sosial}

Patuh pada aturan-aturan sosial adalah sikap menurut dan taat terhadap aturan-aturan berkenaan dengan masyarakat dan kepentingan umum (Kemendiknas, 2010:18). Berdasarkan penelitian ditemukan beberapa karakter patuh pada aturan-aturan sosial seperti dalam Buku 3 (BI/ VII/ N-D-YP) dalam teks “Remaja Liar Gedor Mobil" (hlm. 64). Kutipan tersebut menggambarkan secara oposisional dari karakter patuh pada aturan-aturan 
sosial. Indonesia yang dikenal selama ini penduduknya ramah, akhir-akhir ini diresahkan oleh ulah para remaja liar yang berkeliaran mengganggu pengendara mobil di jalan raya. Aksi remaja liar tersebut kadang melakukan pemalakan atau aksi kekerasan lain yang sangat meresahkan masyarakat, bahkan para turis mancanegara yang datang ke Indonesia. A ksi yang sama dilakukan remaja pada Buku 11 (BBI/ IX/ AYW-S) halaman 135. Dari kutipan tersebut apabila mengikuti pemikiran Jurgen Hubermas, perilaku kaum re maja yang terlibat kehidupan geng sebenarnya sedang mengalami distorsi komunikasi. Kaum remaja tidak mampu memahami atau sengaja tidak mau menye pakati aturan budaya, masyarakat, dan komunitas. Selain itu, aksi kekerasan para remaja disinyalir karena faktor ekonomi dan pengangguran yang meningkat.

Mu'in (2011:41-42) menyatakan bahwa akar kekerasan adalah ketika sistem ekonomi (yang saat ini kapitalistik) membuat banyak orang terteror dengan kebutuhan hidupnya sendiri, tertekan oleh keadaan, dan kemudian melakukan hal-hal yang berada di luar batas-batas kemanusiaan. Sebagaimana Mahatma Gandhi mengatakan, "Akar kekerasan itu adalah kemewahan tanpa bekerja, kesenangan tanpa hati nurani, ilmu tanpa kepribadian, perdagangan tanpa moralitas, sains tanpa humanitas, penyembahan tanpa pengorbanan, politik tanpa prinsip." Dengan adanya nilai karakter ini dalam buku teks, diharapkan peserta didik dapat memiliki perilaku yang positif dalam menyikapi aturan-aturan sosial yang berlaku di masyarakat.

\section{Menghargai Karya dan Prestasi Orang Lain}

Menghargai karya dan prestasi orang lain adalah sikap dan tindakan yang men- dorong dirinya untuk menghasilkan se suatu yang berguna bagi masyarakat, dan mengakui dan menghormati keberhasilan orang lain (Kemendiknas, 2010:18). Karakter ini muncul pada Buku 4 (BSI/ VII/ MS) dalam teks "Gesang, sang Maestro yang Bersahaja" (hlm. 76-78) dan Buku 15 (BIs1.2/ IXB/ P) dalam cerpen "Hadiah $\mathrm{Ke}$ rajinan" (hlm. 50-52B). Siapa yang tidak mengenal Gesang, sang pencipta lagu "Bengawan Solo" (hlm. 76-78). Karyanya yang spektakuler pada bidang seni patut diteladani. Menghargai karya seni ciptaan sang Maestro, Gesang, merupakan salah satu bentuk manifestasi kecintaan pada bangsa. Selain itu, dengan menghargai karya orang lain berarti memiliki sikap toleran dan demokratis sekaligus dapat meneladani kreativitasnya. Begitu pula dalam cerpen "Hadiah Kerajinan" (50-52B) menggambarkan sikap seorang guru yang menghargai karyapeserta didiknya dengan memberikan hadiah. Sikap tersebut dilakukan guru untuk merangsang peserta didik yang lain agar dapat bersaing secara sehat, toleran, dan demokratis terhadap prestasi orang lain.

\section{Santun, Suka M enolong, Tenggang Rasa, G otong Royong, dan Kerja Sama}

Sikap santun dalam buku teks muncul dalam berbagai variasi teks. Sikap santun tersebut, berturut-turut dalam buku teks yang sama, antara lain santun dalam bertelepon seperti pada Buku 1 (BI/ VII/ AA-SN) dalam kutipan teks "Kesopanan dalam Bertelepon" (hlm. 31), santun dan prihatin melihat kepedihan dalam puisi "Sahabatku" (hlm. 84) dan dalam puisi "Kemiskinan" (hlm. 84).

Sikap santun, suka menolong, tabah, dan tulus juga patut diteladani dari dongeng "Hati yang Tulus" (hlm. 116-18A) pada Buku 5 (BIs1.2/ VIIA/P). Dongeng 
tersebut menggambarkan ketulusan hati Mercy yang tabah, ikhlas bersusah payah menerjang semua rintangan mencari obat demi kesembuhan kakeknya. Sikap santun dan tulus yang diperlihatkan Mercy bukan hanya terhadap kakeknya, tetapi terhadap semua orang yang memerlukan pertolongan. Sikap itu diperlihatkan ketika dalam perjalanannya mencari obat untuk kakeknya, setiap menemui orang yang kesusahan selalu ditolongnya. Sikap santun dan solidaritas muncul pula pada Buku 6 (BBI/ VIII/ AYW-S) dalam bentuk petikan drama yang menggambarkan solidaritas anggota PMI pada situasi perang (hlm. 43-44).

Wujud kepekaan dan rasa kemanusiaan dapat pula dilihat pada Buku 12 (BI/ IX/ AA-Y-S) dalam bentuk puisi "Hayatilah Sayang" (hlm. 23) dan lagu "Usah Kau Lara Sendiri" (hlm. 24), Buku 13 (BI/ IX/ N-D-YP) dalam "Bakti Sosial untuk Prajurit" (hlm. 68-69), Buku 15 (BIs1.2/ IXA/ P) dalam "GP A nshor dan Walubi Bangun 3.000 Rumah Korban Tsunami Aceh" (hlm. 18-19), dan teks "Bantuan bagi Korban Terkumpul Rp39 Miliar" (hlm. 19-20).

Selain sikap santun dan suka menolong, karakter lain dalam buku teks adalah gotong-royong. Karakter ini merupakan bentuk karakter bangsa yang sudah dilakukan sejak nenek moyang dulu dan masih berlaku pada masyarakat yang tinggal di daerah pedalaman dan pedesaan. Karakter gotong royong ini muncul dalam bentuk kutipan novel "Pulang" yang muncul sekaligus dalam dua buku, yakni Buku 11 (BBI/ IX/ AWY-S) halaman 59 dan Buku 14 (CTLBI/IX/ NH) halaman 10-12. Kutipan teks tersebut menggambarkan awalnya masyarakat desa yang miskin karena malas membangun desa. Piko yang datang dari perantauan prihatin melihat keadaan desanya. Lewat pidatonya di depan jamaah Jumat, ia berusaha menyadarkan penduduk desanya yang masa bodoh dan bebal untuk bergotong-royong membangun sistem irigasi. Usahanya itu membuat masyarakat desa tersadar yang kemudian melakukan gotong-royong membangun irigasi. Akhirnya, berkat gotong-royong antara sesama masyarakat desa, sawah mereka yang kekeringan menjadi subur kembali dengan adanya sistem irigasi. Itulah gambaran kebersamaan dan gotong-royong yang masih terlihat pada masyarakat di pedesaan yang diharapkan dapat diimplementasikan oleh peserta didik saat ini.

\section{Demokratis, Bijaksana, dan dapat Diper- caya}

Karakter demokratis adalah karakter yang dibangun di atas dasar nilai-nilai demokratis. Chamin (Mustakim, 2011:77) mengatakan bahwa nilai-nilai demokratis, antara lain kebebasan (berpendapat, berkelompok, berpartisipasi) menghormati orang atau kelompok lain, kesetaraan, kerja sama, persaingan, dan kepercayaan.

Salah satu sikap seorang pemimpin yang tidak demokratis dalam suatu kantor terlihat pada kutipan drama "Tuan Amin" (hlm. 24-25) pada Buku 7 (MJIPBSI/ VIII/ DH-BW-SL) Kutipan tersebut menggambarkan sikap seorang pemimpin yang me lihat perbedaan antara pimpinan dan bawahan. Tuan Amin mencerminkan seorang pemimpin yang tidak mau berbicara langsung dengan bawahannya. Menurutnya, pemimpin dan bawahan tidak dapat disamakan derajatnya. Sementara itu, karakter bijaksana juga terdapat dalam buku teks SMP. Karakter bijaksana tersebut muncul dua kali pada Buku 12 (BI/ IX/ AA-Y-S) dalam bentuk kutipan dongeng (hlm. 90), dan dalam bentuk syair "Syair Pesanan Ayahanda (hlm. 21).

Kutipan dongeng (hlm. 90) menggambarkan seorang raja yang bijaksana 
dalam membuat keputusan kepada dua orang ibu yang sama-sama mengaku sebagai pemilik bayi. Berkat kebijaksanaannya, sang raja dapat membuat keputusan dengan adil. Di pihak lain, syair ayahanda (hlm. 21) merupakan syair yang dibuat untuk menasihati pemimpin. Ungkapan syair nasihat moral antara ayah dan anak, merupakan alegori tentang relasi penguasaabdi. Sebuah peringatan kepada raja tanpa menjatuhkan wibawanya di hadapan rakyat. Meskipun raja adalah mudirnya, namun dari segi kekuasaan tetaplah ia raja yang harus dihormati dan dibela oleh RAH. Dengan adanya karakter demokratis dan bijaksana dalam buku teks tersebut, diharapkan mampu menumbuhkan sikap positif pada peserta didik untuk bersikap bijak ketika menjadi seorang pemimpin dalam memutuskan masalah.

\section{Nilai Karakter dalam Hubungannya de- ngan Lingkungan}

Nilai karakter dalam hubungannya dengan lingkungan dengan varian sikap peduli sosial dan lingkungan (Kemendiknas, 2010:18) adalah sikap dan tindakan yang selalu berupaya mencegah kerusakan pada lingkungan alam di sekitarnya, dan mengembangkan upaya-upaya untuk memperbaiki kerusakan alam yang sudah terjadi dan selalu ingin memberi bantuan bagi orang lain dan masyarakat yang membutuhkan.

Dari hasil analisis 15 buku teks ditemukan karakter manusia terhadap lingkungan dengan varian peduli sosial dan lingkungan cukup intensif muncul, yakni sebanyak 83 kali. Varian peduli sosial dan lingkungan terlihat paling banyak muncul pada Buku 6 (BBIVIII/ AWY-S), yakni sebanyak 14 kali, menyusul kemudian Buku 5 (BIs1.2/ VIIAB/P), yakni sebanyak 11 kali dan Buku 1 (BI/ VII/ AA-SN), yakni seba- nyak 10 kali. Selebihnya pada buku-buku teks yang lain kurang dari 10 kali muncul.

Pesan pentingnya memiliki karakter peduli sosial dan lingkungan muncul pada Buku 3 (BI/ VII/ N-D-YP) dalam dongeng "Petuah Pohon Tua" (hlm. 89-90) dan Buku 9 (CTLBI/ VIII/ KL) dalam lagu "Berita Kepada Kawan" (hlm. 168). Ketika manusia merasa sebagai makhluk yang paling berkuasa di bumi, ia merasa berhak mengeksploitasi alam sekehendak hatinya. Dengan demikian, rusaklah alam karena matinya hati nurani manusia. Manusia memanfaatkan alam bukan berdasarkan asas kebutuhan melainkan berdasarkan pada nafsu untuk mengeksploitasi dengan tujuan menumpuk harta. Keserakahan manusia dengan cara merambah, menebang pohon secara serampangan mengakibatkan kerugian besar dalam memelihara keragaman hayati hutan. Selain akan berdampak pada pemusnahan sebagian atau seluruh jenis keragaman sumberdaya hayati hutan, juga akan berdampak buruk pada kehidupan manusia seperti terjadinya kekeringan di musim kemarau dan kebanjiran di musim hujan.

Selain kutipan gambaran kerusakan lingkungan akibat kurang peduli terhadap lingkungan, dalam buku teks juga terdapat kutipan yang membesarkan hati, seperti pada Buku 1 (BI/ VII/ AA-SN) dalam teks "Keindahan Alam Bawah Laut" (hlm.136137) dan "Menjaga Keberadaan Penyu di Pantai Tulaun Sulawesi Utara" (hlm.132133). Kedua kutipan teks tersebut menggambarkan kepedulian terhadap kelangsungan hidup biota laut. Kepedulian terhadap kelestarian bawah laut dengan pencanangan bebas sianida dan sikap nelayan di Minahasa terhadap binatang penyu yang hampir punah merupakan bentuk kesigapan menghadapi tantangan globalisasi. 
Kesadaran pentingnya menjaga lingkungan dari pencemaran udara juga diperlukan seperti pada Buku 7 (MJIPBI/ VIII/ DH-BW-SL) dalam teks "Jadikan Kendaraan Bersahabat dengan Alam" (hlm. 2930). Perlunya upaya menciptakan kota yang bersih, sehat, indah, nyaman, dan rapi diungkap pada Buku 11 (BBI/IX/ AYW-S) halaman 133. Gambaran figur yang peduli lingkungan pada Buku 2 (BIBK/ VII/ SS-S) dalam wawancara "Emil Salim Berjuang untuk 'Planet Biru'" (hlm. 85-88).

Dengan adanya nilai karakter peduli pada lingkungan dalam buku teks diharapkan peserta didik bijak dalam mengelola alam. Dengan memiliki karakter peduli lingkungan, diharapkan peserta didik sadar bahwa sikap baik antara manusia de ngan alam akan melahirkan kebudayaan yang di dalamnya keberlangsungan alam terus terjaga agar usianya yang semakin tua masih kuat memberikan sumber-sumber kehidupan bagi umat manusia. Kemiskinan perlu diberantas, produksi pangan perlu ditingkatkan, tetapi bukan dengan eksploitasi sumber daya alam, melainkan dengan pemerkayaan sumber daya alam.

\section{Nilai Kebangsaan}

Nilai kebangsaan merupakan cara berpikir, bertindak, dan berwawasan yang menempatkan kepentingan bangsa dan negara di atas kepentingan diri dan kelompoknya. Nilai kebangsaan ini terdiri atas nasionalis dan menghargai keberagaman (Kemendiknas, 2010:19). Berdasarkan hasil analisis pada 15 buku teks pelajaran ditemukan bahwa nilai kebangsaan muncul sebanyak 118 kali yang terbagi dalam nasionalis sebanyak 97 kali dan menghargai keberagaman sebanyak 21 kali. Nilai kebangsaan terlihat dominan muncul pada buku kelas VII terbitan Depdiknas, yakni ratarata 12 kali muncul.

Nasionalis. Beberapa nilai karakter nasionalis terlihat dalam buku teks BSI, seperti pada Buku 2 (BIBK/ VII/ SS-S) dalam kutipan teks "Benderaku" (hlm. 140) dan "Berdiri di Atas Kaki Sendiri" (hlm.152153). Kehebatan tokoh Diponegoro dalam melawan penjajah dapat menggugah jiwa nasionalisme generasi muda, muncul bersamaan dalam dua buku teks, yakni pada Buku 1 (BI/ VII/ AA-SN) halaman 97 dan Buku 3 (BI/ VII/ N-D-YP) halaman 39-40. Para pahlawan dahulu membela bangsa dengan mengusir penjajah, sedangkan generasi muda saat ini mengisi kemerdekaan dengan belajar dan bekerja keras.

Sikap nasionalis dalam bentuk kecintaan kepada pemerintah muncul pada Buku 1 (BI/ VII/ AA-SN) dalam teks "Sri Sultan Hamengku Buwono IX" (hlm. 121122), bangga terhadap produk negeri sendiri muncul pada Buku 4 (BSI / VII/ MS) dalam teks "Tanda untuk Lindungi Batik Indonesia" (hlm. 94-95), Buku 8 (BI/ VIII/ N-D-YP) dalam puisi "Cintailah Rupiah" (hlm. 168-169), dan Buku 10 (Bls1.2/ VIIIA/P) dalam teks "Mooryati Soedibyo Tak Henti Memperkenalkan Jamu Indonesia" (hlm.133A. Di pihak lain, pada Buku 9 (CTLBI/ VIII/ KL) merupakan kritik Taufik Ismail terhadap pemerintah lewat puisi "Kembalikan Indonesia Padaku" (hlm. 168).). Batik dan jamu merupakan produk Indonesia yang perlu dibanggakan. Adapun puisi "Cintailah Rupiah" merupakan kritik terhadap pemerintah dan kalangan elit kaya yang mengumbar perintah untuk cinta pada rupiah. Padahal, mereka sendiri lebih memilih menukar rupiah dengan dolar. Rakyat semakin tidak tahan dengan ulah munafik pemerintah dan para elit kaya. Sikap nasionalis semu di kalangan pemuka negeri dengan berpura-pura ber- 
pancasila memuakkan rakyat kecil. Bagaimana rakyat dapat berkarakter nasionalis, kalau pejabat dan para elit kaya di depan mata penuh dengan riya dan dusta berpura-pura memiliki jiwa nasionalis.

Konteks lain diungkap pada Buku 10 (BIs1.2/ VIIIA/ P) dalam kutipan "Mengarungi Lautan Menyatukan Bangsa" (hlm. 57-58A). Kutipan tersebut menggambarkan upaya penyadaran generasi muda untuk meningkatkan rasa nasionalisme dan rasa cinta tanah air melalui promosi potensi budaya dan tradisi lewat kegiatan kepariwisataan. Melalui kegiatan wisata bahari diharapkan generasi muda dapat memahami bahwa potensi tiap daerah berbeda namun berada dalam satu kesatuan, yakni negara Indonesia sehingga ancaman disintegrasi bangsa dapat ditepis. Selain itu, wisata bahari diharapkan dapat me nyadarkan generasi muda bahwa transportasi laut merupakan salah satu sarana pemersatu bangsa.

Menghargai Keberagaman. Karakter terakhir yang ditemukan dalam penelitian ini adalah menghargai keberagaman atau multikulturalisme. Karakter ini muncul pada Buku 2 (BIBK/ VII/ SS-S) dalam petikan wawancara "Belahan Dunia Muslim mana yang paling menarik bagi Anda?" (hlm. 159-160), Buku 7 (BJIPBSI/ VIII/ DH-BW-SL) dalam kutipan novel "Perempuan Kembang Jepun" (hlm.116-118), dan Buku 9 (CTLBI/ VIII/ KL) dalam kutipan teks "Membangun Semangat Menghargai Perbedaan" (hlm. 6). Teks "Membangun Semangat Menghargai Perbedaan" menggambarkan Indonesia yang memiliki beragam, suku, bahasa, budaya, adat-istiadat. Banyaknya perbedaan ini memiliki dua sisi mata uang. A pabila semangat kebersamaan selalu dibangun dan ditumbuhkembangkan akan menuai keindahan. Namun, bila semangat kecurigaan yang ditumbuhsuburkan akan menuai beragam bencana.

Membangun semangat menghargai perbedaan perlu terus didengung-dengungkan dan diharapkan dapat diimplementasikan oleh peserta didik supaya bangsa ini tidak mudah panas bila berbeda, tidak mudah gatal bila berbeda, tidak berprasangka negatif kepada kelompok yang berbeda, tidak merasa diri yang terbaik. Semangat membangun kebersamaan untuk menciptakan kehidupan yang aman perlu terus dikobarkan.

\section{PENUTUP}

Buku teks pelajaran Bahasa Indonesia yang dibutuhkan guru dan peserta didik bukan hanya semata-mata menyajikan materi kebahasaan dan kesastraan untuk mewujudkan kemahiran berbahasa dan bersastra melainkan buku ajar yang di dalamnya memuat dan mengintegrasikan nilainilai pendidikan karakter. Nilai pendidikan karakter mencakupi lima hubungan karakter, yakni nilai karakter dalam hubungannya dengan Tuhan YME, diri sendiri, sesama, lingkungan, dan bangsa. Dari lima hubungan karakter yang dicanangkan dalam penelitian, yakni karakter manusia terhadap Tuhan, diri sendiri, sesama, lingkungan, dan karakter manusia terhadap bangsa, hanya karakter manusia terhadap Tuhan YME yang paling sedikit ditemukan. Di pihak lain, dari lima belas buku teks pelajaran, ditemukan hubungan karakter manusia terhadap diri sendiri dan karakter manusia terhadap sesama yang paling dominan. Dominannya hubungan karakter manusia terhadap diri sendiri dan sesama menyiratkan bahwa penulis buku ingin menekankan pada aspek manusianya yang memiliki kehidupan pribadi dan kehidupan sosial. Aspek yang paling domi- 
nan selanjutnya adalah hubungan karakter manusia terhadap lingkungan dan bangsa.

\section{UCAPAN TERIMA KASIH}

Terima kasih diucapkan kepada Prof. Dr. Burhan Nurgiyantoro selaku pembimbing tesis ini. Ucapan terima kasih juga disampaikan kepada reviuer dan pembaca ahli yang telah memberikan masukan berharga untuk penyempurnaan artikel ini.

\section{DAFTAR PUSTAKA}

Bahan Pelatihan Penguatan Metodologi Pembelajaran Berdasarkan Nilai-nilai Budaya untuk Membentuk Daya Saing dan Karakter Bangsa: Pengembangan Pendidikan Kewirausahaan. Jakarta: Kemendiknas.

Cunningsworth, Alan. 1995. Choosing Y our Coursebook. Oxford: Heinemann.

Harmer, J. 2007. The Practical of English Language Teaching ( $4^{\text {th }}$ ed.). London: Longman.

Hartono. 2011. "Fight Against Corruption, Religious Tolerance \& Gender Equality in English School Books a Study of English Books for Senior High Schools Distributed in Central Java." Proceedings the $58^{\text {th }}$ Teflin International Conference Language Teaching and Character Building. Semarang, h. 306310.

Kemendiknas. 2010. Panduan Pendidikan Karakter di Sekolah M enengah Pertama. Jakarta: Kemendiknas.

Kurniawan, Khaerudin. 2011. “Pengembangan Buku Teks Bahasa Indonesia SD Berbasis Nilai, Budaya, dan Karakter Bangsa: Bunga Rampai Purnabakti Prof. Dr. Yoyo Mulyana, M. Ed." Dalam Kholid A. Harras dan
Ma'mur Saadie (ed). Pendidikan Sastra \& Karakter Bangsa, (hlm. 276-295). Bandung: Jurdiksastrasia FPBS UPI.

Lickona, T. 1991. Educating For Character: How Our Schools Can Teach Respect and Responsibility. New York: Bantam Books.

Mu'in, Fatchul. 2011. Pendidikan karakter: Konstruksi Teoretis \& Praktik. Jogyakarta: Ar-Ruzz M edia.

Muslich, Masnur. 2010. Text Book Writing: D asar-dasar Pemahaman, Penulisan, dan Pemakaian Buku Teks. Ar-Ruzz Media: Yogyakarta.

Mustakim, Bagus. 2011. Pendidikan karakter: M embangun Delapan Karakter Emas $M$ anusia Indonesia Bermartabat. Yogyakarta: Samudera Biru.

Nurgiyantoro, Burhan. 2013. Sastra Anak: Pengantar Pemahaman Dunia Anak. Yogyakarta: Gadjah Mada Unversity Press.

Nurgiyantoro, Burhan \& Anwar Efendi. 2013. "Prioritas Penentuan Nilai Pendidikan Karakter dalam Pembelajaran Sastra Remaja". Cakrawala Pendidikan, Th. XXXII, N o.3, hlm. 382-393.

Peraturan Menteri Pendidikan Nasional No. Nomor 23 Tahun 2006 tentang SKL untuk Pendidikan Dasar dan Menengah.

Peraturan Menteri Pendidikan Nasional No. 22 Tahun 2006, tentang SK/ KD SI untuk Pendidikan Dasar dan Menengah.

Pusat Bahasa Departemen Pendidikan Nasional. 2008. Kamus Bahasa Indonesia. Jakarta: Pusat Bahasa. Cet. I. 


\section{Lampiran}

Tabel Pemunculan Wujud Unsur Pendidikan Karakter dalam Buku Teks Pelajaran Bahasa Indonesia di Daerah Istimewa Yogyakarta

\begin{tabular}{|c|c|c|c|c|c|c|c|c|c|c|c|c|c|c|c|c|c|c|c|c|}
\hline \multirow[t]{2}{*}{ No. } & \multicolumn{2}{|c|}{$\begin{array}{c}\text { Wujud Unsur Pendidikan } \\
\text { Karakter }\end{array}$} & \multicolumn{16}{|c|}{ Buku Teks Pelajaran Bahasa Indonesia SM P } & \multicolumn{2}{|c|}{$\begin{array}{c}\text { Jumlah/ } \\
\text { Unsur }\end{array}$} \\
\hline & Substansi & Varian & 1 & 2 & 3 & 4 & 5 & 6 & 7 & 8 & 9 & 10 & & 1 & 12 & 13 & 14 & 15 & $\sum$ & $\%$ \\
\hline \multirow[b]{2}{*}{1.} & \multirow{2}{*}{$\begin{array}{l}\text { Nilai } \\
\text { Karakter } \\
\text { dalam } \\
\text { Hubungannya } \\
\text { dengan Tuhan }\end{array}$} & $\begin{array}{l}\text { Taat kepada } \\
\text { Tuhan YME }\end{array}$ & 1 & 5 & 3 & - & - & 2 & 3 & 4 & 8 & 5 & & 3 & 3 & 5 & 4 & 6 & 52 & 5.7 \\
\hline & & $\begin{array}{l}\text { Bersyukur, } \\
\text { Tawakal (Berserah } \\
\text { Diri kepada } \\
\text { Tuhan) }\end{array}$ & 1 & 2 & 2 & 2 & 2 & 1 & 2 & 1 & 1 & - & & 3 & - & 5 & 2 & 1 & 25 & 2.7 \\
\hline \multirow{2}{*}{\multicolumn{2}{|c|}{ Jumlah Bagian 1}} & Frekuensi & 2 & 7 & 5 & 2 & 2 & 3 & 5 & 5 & 9 & 5 & ( & 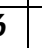 & 3 & 10 & 6 & 7 & 77 & 8.44 \\
\hline & & Persentase & 0.22 & 0.8 & 0.5 & 0.2 & 0.2 & 0.3 & 0.5 & 0.5 & 1 & 0.5 & 0. & $66 \mid 0$ & 0.33 & 1.1 & 0.66 & 0.77 & 8.44 & \\
\hline \multirow{12}{*}{2.} & \multirow{12}{*}{$\begin{array}{l}\text { Nilai } \\
\text { Karakter } \\
\text { dalam } \\
\text { Hubungannya } \\
\text { dengan } \\
\text { Diri Sendiri }\end{array}$} & $\begin{array}{l}\text { Jujur, A dil, } \\
\text { Rendah Hati }\end{array}$ & 6 & 4 & 2 & 4 & 1 & 3 & 4 & 1 & - & 1 & & 5 & 5 & 7 & 1 & 5 & 49 & 5.37 \\
\hline & & $\begin{array}{l}\text { Bertanggung } \\
\text { Jawab,Mandiri }\end{array}$ & 2 & 1 & - & 4 & 2 & 2 & - & - & 1 & - & & 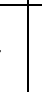 & - & - & 2 & 2 & 16 & 1.75 \\
\hline & & $\begin{array}{l}\text { Bergaya Hidup } \\
\text { Sehat }\end{array}$ & 9 & - & - & 6 & 4 & 5 & 8 & 9 & 2 & 1 & & 4 & - & 4 & 3 & - & 55 & 6.03 \\
\hline & & $\begin{array}{l}\text { Rajin, Disiplin, } \\
\text { Tertib, Hemat, } \\
\text { Sportif, Tegas }\end{array}$ & 7 & 5 & 4 & 2 & 3 & 3 & 7 & 3 & - & 13 & & 9 & 5 & 12 & 5 & 1 & 79 & 8.66 \\
\hline & & $\begin{array}{l}\text { Semangat dan } \\
\text { Kerja Keras }\end{array}$ & 3 & 1 & 1 & 3 & 3 & 2 & 3 & 1 & 6 & 3 & & 3 & 11 & 4 & 4 & 2 & 50 & 5.48 \\
\hline & & Percaya Diri & 2 & 2 & 2 & - & - & 1 & - & & 1 & 2 & & 3 & 3 & 3 & - & 1 & 12 & 1.31 \\
\hline & & $\begin{array}{l}\text { Berjiwa } \\
\text { Wirausaha }\end{array}$ & 1 & - & - & 4 & 1 & - & 11 & 6 & - & 2 & & 3 & - & 3 & 2 & 6 & 39 & 4.27 \\
\hline & & $\begin{array}{l}\text { Berpikir Logis, } \\
\text { Kritis, Kreatif, } \\
\text { Inovatif , Cerdas }\end{array}$ & 2 & 3 & 3 & 5 & 5 & 8 & 3 & 4 & 6 & 5 & & $?$ & 4 & 6 & 4 & 4 & 62 & 6.79 \\
\hline & & Ingin Tahu & - & - & 2 & 9 & 1 & 1 & - & - & - & - & & & - & - & 3 & - & 3 & 0.32 \\
\hline & & $\begin{array}{l}\text { Cinta IImu, } \\
\text { Gemar Membaca }\end{array}$ & 2 & 1 & 4 & 2 & 2 & 3 & - & 1 & - & 1 & & 2 & 3 & 3 & 1 & 2 & 25 & 2.74 \\
\hline & & $\begin{array}{l}\text { Tabah dan Sabar, } \\
\text { Ikhlas, Loyal, } \\
\text { Menepati Janji }\end{array}$ & 1 & 2 & 1 & - & - & - & 2 & 1 & 2 & - & & 2 & 3 & 3 & - & 6 & 23 & 2.52 \\
\hline & & $\begin{array}{l}\text { Teliti, Cermat, } \\
\text { Hati-hati }\end{array}$ & 1 & - & 1 & 1 & - & 1 & 3 & - & - & 1 & & L & - & 2 & 2 & 2 & 15 & 1.64 \\
\hline \multirow{2}{*}{\multicolumn{2}{|c|}{ Jumlah Bagian 2}} & Frekuensi & 36 & 19 & 20 & 40 & 22 & 29 & 41 & 26 & 18 & 25 & & 4 & 34 & 47 & 27 & 31 & 428 & 46.9 \\
\hline & & Persentase & 3.95 & 2.1 & 2.2 & 4.4 & 2.4 & 3.2 & 4.5 & 2.9 & 3.2 & 3. & 23. & 733 & 3.73 & 5.15 & 2.96 & 3.4 & 46.9 & \\
\hline \multirow{3}{*}{3.} & \multirow{3}{*}{$\begin{array}{l}\text { Nilai } \\
\text { Karakter } \\
\text { dalam } \\
\text { Hubungannya } \\
\text { dengan } \\
\text { Sesama }\end{array}$} & $\begin{array}{l}\text { Sadar akan Hak } \\
\text { dan Kewajiban } \\
\text { Diri dan Orang } \\
\text { Lain }\end{array}$ & 1 & - & 1 & 1 & 2 & - & 2 & - & 2 & - & & & - & - & - & 2 & 11 & 1.20 \\
\hline & & $\begin{array}{l}\text { Patuh pada } \\
\text { Aturan Sosial }\end{array}$ & 1 & 1 & - & - & - & - & 1 & - & - & 2 & & & 1 & - & - & - & 6 & 0.65 \\
\hline & & $\begin{array}{l}\text { Menghargai } \\
\text { Karya dan } \\
\text { Prestasi Orang } \\
\text { Lain }\end{array}$ & 1 & 1 & 3 & 2 & 1 & - & - & - & - & 2 & & 3 & 2 & 4 & - & 1 & 20 & 2.19 \\
\hline
\end{tabular}




\begin{tabular}{|c|c|c|c|c|c|c|c|c|c|c|c|c|c|c|c|c|c|c|c|}
\hline \multirow[t]{4}{*}{ No. } & \multicolumn{2}{|c|}{$\begin{array}{c}\text { Wujud Unsur Pendidikan } \\
\text { Karakter }\end{array}$} & \multicolumn{15}{|c|}{ Buku Teks Pelajaran Bahasa Indonesia SM P } & \multicolumn{2}{|c|}{$\begin{array}{l}\text { Jumlah/ } \\
\text { Unsur }\end{array}$} \\
\hline & Substansi & Varian & 1 & 2 & 3 & 4 & 5 & 6 & 7 & 8 & 9 & 10 & \begin{tabular}{|l|l|}
11 \\
\end{tabular} & 12 & 13 & 14 & 15 & $\sum$ & $\%$ \\
\hline & & $\begin{array}{l}\text { Santun, Lembut, } \\
\text { Baik H ati , Suka } \\
\text { Menolong, } \\
\text { Tenggang Rasa, } \\
\text { Gotong Royong, } \\
\text { dan Kerja Sama }\end{array}$ & 3 & 10 & 9 & 7 & 9 & 4 & 7 & 8 & 6 & 9 & 4 & 9 & 12 & 13 & 15 & 125 & 13.7 \\
\hline & & $\begin{array}{l}\text { Demokratis, } \\
\text { Bijaksana dan } \\
\text { dapat Dipercaya }\end{array}$ & 1 & - & 1 & 1 & 2 & 3 & 3 & 2 & - & 1 & 2 & 2 & 1 & 1 & 4 & 24 & 2.63 \\
\hline \multirow{2}{*}{\multicolumn{2}{|c|}{ Jumlah Bagian 3}} & Frekuensi & 6 & 12 & 14 & 11 & 14 & 7 & 13 & 10 & 8 & 14 & \begin{tabular}{|l|}
9 \\
\end{tabular} & 14 & 13 & 14 & 22 & 186 & 20.4 \\
\hline & & Persentase & 0.66 & 1.3 & 1.5 & 1.2 & 1.5 & 0.8 & 1.4 & 1.1 & 0.9 & 1.5 & 0.99 & 1.54 & 1.43 & 1.54 & 2.41 & 20.4 & \\
\hline 4. & $\begin{array}{l}\text { Nilai } \\
\text { Karakter dlm } \\
\text { Hubungannya } \\
\text { dengan } \\
\text { Lingkungan }\end{array}$ & $\begin{array}{l}\text { Peduli Sosial dan } \\
\text { Lingkungan }\end{array}$ & 10 & 6 & 3 & 14 & 5 & 3 & 2 & 4 & 2 & 8 & 2 & 6 & 5 & 11 & 2 & 83 & 9.10 \\
\hline \multirow{2}{*}{\multicolumn{2}{|c|}{ Jumlah Bagian 4}} & Frekuensi & 10 & 6 & 3 & 14 & 5 & 3 & 2 & 4 & 2 & 8 & 2 & 6 & 5 & 11 & 2 & 83 & 9.1 \\
\hline & & Persentase & 1.1 & 0.7 & 0.3 & 1.5 & 0.5 & 0.3 & 0.2 & 0.4 & 0.2 & 0.9 & 0.22 & 0.66 & 0.55 & 1.21 & 0.22 & 9.1 & \\
\hline \multirow[b]{2}{*}{5.} & \multirow{2}{*}{$\begin{array}{l}\text { Nilai } \\
\text { Kebangsaan }\end{array}$} & Nasionalis & 12 & 8 & 11 & 9 & 10 & 9 & 5 & 2 & 1 & 6 & 2 & 8 & 7 & 3 & 4 & 97 & 10.6 \\
\hline & & $\begin{array}{l}\text { Menghargai } \\
\text { keberagaman }\end{array}$ & 0 & 1 & 1 & 3 & 2 & 3 & 1 & 1 & - & 2 & - & - & 4 & 2 & 1 & 21 & 2.30 \\
\hline \multirow{2}{*}{\multicolumn{2}{|c|}{ Jumlah Bagian 5}} & Frekuensi & 12 & 9 & 12 & 12 & 12 & 12 & 6 & 3 & 1 & 8 & \begin{tabular}{|l|}
2 \\
\end{tabular} & 8 & 11 & 5 & 5 & 118 & 12.9 \\
\hline & & Persentase & 1.32 & 1 & 1.3 & 1.3 & 1.3 & 1.3 & 0.7 & 0.9 & 0.1 & 0.9 & 0.22 & 0.88 & 1.21 & 0.55 & 0.55 & 12.9 & \\
\hline \multirow{2}{*}{\multicolumn{2}{|c|}{$\begin{array}{l}\text { JUMLAH } \\
\text { TOTAL }\end{array}$}} & $\begin{array}{l}\text { FREKUENSI } \\
\text { PEMUN CULAN }\end{array}$ & 66 & 53 & 54 & 79 & 55 & 54 & 67 & 48 & 38 & 64 & 53 & 65 & 86 & 63 & 67 & 912 & \\
\hline & & PERSENTASE & 7.24 & 5.8 & 5.9 & 8.7 & 6 & 5.9 & 7.3 & 5.3 & 4.2 & 7.02 & $5.81[7$ & 7.13 & 9.43 & 6.91 & 7.35 & 100 & \\
\hline
\end{tabular}

